\title{
Specific formulas for preterm infants, how and when
}

\author{
Antonio Alberto Zuppa ${ }^{*}$, Piero Catenazzi, Riccardo Riccardi, Costantino Romagnoli \\ From XXI Congress of the Italian Society of Neonatology \\ Palermo, Italy. 24-26 September 2015
}

Both ESPGHAN (2010) and AAP (2012), stated that "all preterm infants should receive human milk" for the many short-term and long termbenefits [1,2].

All kinds of breast milk (fresh by own mother or pastourized by donor) for preterm should be fortified, to gain the recommended requirements.

In case of its absence the only alternative is represented by the formulas for preterm infants (PTF).

It is not yet definitively established the ideal PTF composition, particularly for ELBW infants. Table 1 shows the main recommendations for nutrients [1-4].

A study compared the use of a soy-based formula (with calcium, phosphorus and vitamin D), with a PTF. Infants taking soy showed lower growth, levels of protein and albumin [5]. ESPGHAN in 2006 concluded that soy-based formulas should not be used in premature infants [6].

The use of hydrolyzed formulas has not shown a preventive role on cow's milk protein allergy, it has proven helpful in improving food tolerance (acceleration of the intestinal transit time and faster achievement of full enteral feeding), but it has a reduced nutritional value, (especially protein intake) [7-11].

A recent study evaluated the usefulness of a thickened formula in reducing apnea of prematurity GERD-related. The authors conclude that these formulas are not effective in the reduced number of apneas GERD-related [12].

Table 1 Recommended intakes for macro and micronutrients [1-4]

\begin{tabular}{|c|c|c|}
\hline Nutrient & $\begin{array}{l}\text { Per } 100 \\
\text { kcal }\end{array}$ & Recommendations \\
\hline Energy, Kcal & - & $\begin{array}{l}\text { A reasonable range of energy intake for healthy growing preterm infants with adequate protein intake is } 110 \text { to } 135 \\
\qquad \mathrm{kcal}^{*} \mathrm{~kg}^{-1 *} \mathrm{day}^{-1}\end{array}$ \\
\hline $\begin{array}{l}\text { Protein, } g \\
\text { (VLBW) }\end{array}$ & $3,3-3,6$ & $\begin{array}{l}\text { Protein supply needs to compensate for the accumulated protein deficit observed in almost all small preterm infants. } \\
\text { The quality of the provided protein may interfere with the recommended intake because the infant does not require } \\
\text { proteins but requires specific aminoacids. Whey predominant protein with reduced glycomacropeptide and } \alpha \text { - } \\
\text { actalbumin enrichment could be used to optimize the amino acid profile. }\end{array}$ \\
\hline $\begin{array}{l}\text { Protein, } g \\
\text { (ELBW) }\end{array}$ & $3,6-4,1$ & \\
\hline $\begin{array}{l}\text { Carbohydrates, } \\
\qquad \mathrm{g}\end{array}$ & $10,5-12$ & $\begin{array}{l}\text { According to the relatively reduced intestinal lactase activity, the lactose content could be relatively reduced and } \\
\text { replaced by glucose polymers with the characteristic of maintaining the low osmolality of the formulas. }\end{array}$ \\
\hline Lipids, $g$ & $4,4-6$ & $\begin{array}{l}\text { In order to improve fat absorption, an important quota of fat could be given as medium-chain triglycerides with a } \\
\text { maximum of } 30-40 \% \text { of lipid content. }\end{array}$ \\
\hline Calcium, mg & $110-130$ & The calcium to phosphorus ratio $(1,5-2)$ may be an important determinant of calcium absorption and retention. \\
\hline Phosphate, mg & $55-80$ & \\
\hline Iron, $g$ & $1,7-2,7$ & $\begin{array}{c}\text { Iron is essential for brain development, and prevention of iron deficiency is important. Prophylactic enteral iron } \\
\text { supplementation (given as a separate iron supplement) should be started at } 2 \text { to } 6 \text { weeks of age ( } 2-4 \text { weeks in } \\
\text { extremely-low-birth- weight infants) and should be continued after discharge, at least until } 6 \text { to } 12 \text { months of age } \\
\text { depending on diet. }\end{array}$ \\
\hline
\end{tabular}

* Correspondence: zuppaaa@rm.unicatt.it

Department of Pediatrics, Division of Neonatology, Catholic University of the Sacred Heart, Rome, Italy creativecommons.org/licenses/by/4.0), which permits unrestricted use, distribution, and reproduction in any medium, provided the original work is properly cited. The Creative Commons Public Domain Dedication waiver (http://creativecommons.org/publicdomain/ zero/1.0/) applies to the data made available in this article, unless otherwise stated. 
In recent reviews post-discharge formulas does not seem to provide benefits, especially for the heterogeneity of the studies $[3,13]$. They may be useful for infants with GA $<33$ weeks, particularly those $<30$ weeks, with growth at discharge below the 10th percentile (the ESPGHAN recommended their use up to 40 weeks, and for a further 12 weeks if necessary) [3].

Studies about GOS and FOS showed an increase of bifidobacteria in the stool, a reduction in their viscosity and an acceleration of intestinal transit time, resulting in an easier achievement of full enteral feeding $[14,15]$. It is also assumed a role in the prevention of NEC and LOS. Even though they have proven their beneficial role, further studies are needed to establish the type and dose [16].

Several RCTs and recent reviews have shown a benefit of prebiotics in reducing NEC andin the achievement of full enteral feeding [17-19]. Further studies are needed to establish dose, strains and routes of administration [1].

Lactoferrin, both human and bovine, seems to have a significant role as a protective agent against NEC and LOS [20-23].

The available data do not allow to recommend formula supplementation with these substances with functional properties.

\section{Published: 24 September 2015}

\section{References}

1. Agostoni C, Buonocore G, Carnielli VP, De Curtis M, Darmaun D, Decsi T, ESPGHAN Committee on Nutrition: Enteral nutrient supply for preterm infants: commentary from the European Society of Paediatric Gastroenterology, Hepatology and Nutrition Committee on Nutrition. J PediatrGastroentero/Nutr 2010, 50(1):85-91.

2. Johnston M, Landers S, Noble L, Szucs K, Viehmann L: Breastfeeding and the use of human milk. Pediatrics 2012, 129(3):e827-841.

3. Tudehope DI, Page D, Gilroy M: Infant formulas for preterm infants: inhospital and post-discharge. J Paediatr Child Health 2012, 48(9):768-776.

4. De Curtis M, Rigo J: The nutrition of preterm infants. Early Hum Dev 2012, 88(Suppl 1):S 5-7.

5. Hall RT, Callenbach JC, Sheehan MB, Hall FK, Thibeault DW, Kurth CG, Bowen SK: Comparison of calcium- and phosphorus-supplemented soy isolate formula with whey-predominant premature formula in very low birth weight infants. J PediatrGastroenterolNutr 1984, 3(4):571-576.

6. ESPGHAN Committee on Nutrition, Agostoni C, Axelsson I, Goulet O, Koletzko B, Michaelsen KF, Puntis J, Rieu D, Rigo J, Shamir R, Szajewska H, Turck D: Soy protein infant formulae and follow-on formulae: a commentary by the ESPGHAN Committee on Nutrition. $J$ Pediatr Gastroenterol Nutr 2006, 42(4):352-361

7. Zuppa AA, Visintini F, Cota F, Maggio L, Romagnoli C, Tortorolo G: Hydrolysed milk in preterm infants: an open problem. ActaPaediatr 2005, 94(449):84-86, Suppl.

8. Maggio L, Zuppa AA, Sawatzki G, Valsasina R, Schubert W, Tortorolo G: Higher urinary excretion of essential amino acids in preterm infants fed protein hydrolysates. ActaPaediatr 2005, 94(1):75-84.

9. Florendo KN, Bellflower B, van Zwol A, Cooke RJ: Growth in preterm infants fed either a partially hydrolyzed whey or an intact casein/whey preterm infant formula. J Perinatol 2009, 29(2):106-111.

10. Corvaglia L, Mariani E, Aceti A, Galletti S, Faldella G: Extensively hydrolyzed protein formula reduces acid gastro-esophageal reflux in symptomatic preterm infants. Early Hum Dev 2013, 89(7):453-455.
11. Yu MX, Zhuang SQ, Wang DH, Zhou XY, Liu XH, Shi LP, Yue SJ, Qian JH, Sun $\mathrm{JH}$ : Effects of extensively hydrolyzed protein formula on feeding and growth in preterm infants: a multicenter controlled clinical study. Zhongguo Dang Dai ErKeZaZhi 2014, 16(7):684-690.

12. Corvaglia L, Spizzichino M, Aceti A, Legnani E, Mariani E, Martini S, Battistini B, Faldella G: A thickened formula does not reduce apneas related to gastroesophageal reflux in preterm infants. Neonatology 2013 103(2):98-102.

13. Henderson G, Fahey T, McGuire W: Nutrient-enriched formula versus standard term formula for preterm infants following hospital discharge. Cochrane Database Syst Rev 2007, 17(4):CD004696.

14. Mihatsch WA, Hoegel J, Pohlandt F: Prebiotic oligosaccharides reduce stool viscosity and accelerate gastrointestinal transport in preterm infants. Acta Paediatr 2006, 95:843-848.

15. Kapiki A, Costalos C, Oikonomidou C, et al: The effect of a fructooligosaccharide supplemented formula on gut flora of preterm infants. Early Hum Dev 2007, 83:335-339.

16. Srinivasjois $R$, Rao $S$, Patole $S$ : Prebiotic supplementation in preterm neonates: updated systematic review and meta-analysis of randomised controlled trials. ClinNutr 2013, 32(6):958-965.

17. Deshpande G, Rao S, Patole S: Probiotics for prevention of necrotisingenterocolitis in preterm neonates with very low birthweight: a systema- tic review of randomised controlled trials. Lancet 2007, 369:1614-1620.

18. Athalye-Jape G, Deshpande G, Rao S, Patole S: Benefits of probiotics on enteral nutrition in preterm neonates: a systematic review. Am J ClinNutr 2014, 100(6):1508-1519.

19. AlFaleh $\mathrm{K}$, Anabrees J: Probiotics for prevention of necrotizing enterocolitis in preterm infants. Evid Based Child Health 2014, 9(3):584-671.

20. Sharma D, Shastri S: Lactoferrin and Neonatology-Role in neonatal sepsis and necrotizing enterocolitis: Present, past and future. J Matern Fetal \& Neonatal Med 2015, 17:1-8.

21. Italian Task Force for the Study and Prevention of Neonatal Fungal Infections, Italian Society of Neonatology, Manzoni P, Rinaldi M, Cattani S, et al: Bovine lactoferrin supplementation for prevention of late-onset sepsis in very low-birth-weight neonates: a randomized trial. JAMA 2009, 302(13):1421-1428

22. Italian Task Force for the Study and Prevention of Neonatal Fungal Infections-the Italian Society of Neonatology, Manzoni P, Stolfi I, Messner H, et al: Bovine lactoferrin prevents invasive fungal infections in very low birth weight infants: a randomized controlled trial. Pediatrics 2012, 129(1):116-123.

23. Manzoni $P$, Meyer M, Stolfi I, et al: Bovine lactoferrin supplementation for prevention of necrotizing enterocolitis in very-low-birth-weight neonates: a randomized clinical trial. Early Hum Dev 2014, 90(Suppl 1):S 60-65

doi:10.1186/1824-7288-41-S1-A46

Cite this article as: Zuppa et al:: Specific formulas for preterm infants, how and when. Italian Journal of Pediatrics 2015 41(Suppl 1):A46.

\section{Submit your next manuscript to BioMed Central and take full advantage of:}

\footnotetext{
- Convenient online submission

- Thorough peer review

- No space constraints or color figure charges

- Immediate publication on acceptance

- Inclusion in PubMed, CAS, Scopus and Google Scholar

- Research which is freely available for redistribution
} 